\title{
PENEGAKAN DISIPLIN PEGAWAI NEGERI SIPIL DI KANTOR URUSAN AGAMA KECAMATAN MONCONGLOE KABUPATEN MAROS
}

\author{
Andi Mustamin ${ }^{1}$, Abdul Kadir Adys ${ }^{2}$, Adnan Ma'ruf ${ }^{3}$ \\ ${ }^{1)}$ Mahasiswa Jurusan Ilmu Administrasi Negara Unismuh Makassar \\ ${ }^{2)}$ Dosen Jurusan Ilmu Administrasi Negara Unismuh Makassar \\ ${ }^{3)}$ Dosen Jurusan Ilmu Administrasi Negara Unismuh Makassar
}

\begin{abstract}
The research aims to describe the highlight of civil servants dicipline of district religious affairs subdistrict Moncongloe of Maros regency. This research using desciptive qualitative approach. The sample consists of five people are selected by purposively. The data is resulted by doing the observation and interview. The results showed that (1) the highlight of civil servants discipline at the office of religious affairs subdistrict Moncongloe of Maros is running well due to the head conducted self imposed discipline approach. (2) the application punishment at district affairs at Moncongloe Subdistrict at Maros Regency based on the procedure that have been stated. The discipline punishment given is light punisment.
\end{abstract}

Keywords: Discipline, civil servers, and the office of religious affairs.

\begin{abstract}
ABSTRAK
Tujuan penelitian ini adalah untuk menggambarkan penegakan disiplin pegawai negeri sipil di kantor urusan agama kecamatan Moncongloe kabupaten Maros. Penelitian ini menggunakan pendekatan deskriptif kualitatif. Informan dalam penelitian ini terdiri atas lima orang, dimana dipilih secara purposive. Data-data dalam penelitian ini diperoleh dengan cara penyebaran observasi dan wawancara. Hasil penelitian menunjukkan bahwa: (1) penegakan disiplin pegawai negeri sipil di kantor urusan agama kecamatan Moncongloe kabupaten Maros berjalan dengan baik karena kepala kantor urusan agama melakukan pendekatan self imposed dicipline, dan (2) penerapan hukuman disiplin pegawai negeri sipil di kantor urusan agama kecamatan Moncongloe kabupaten Maros berdasarkan prosedurprosedur yang telah ditetapkan. Pemberian hukuman disiplin yang dilakukan adalah disiplin ringan.
\end{abstract}

Kata Kunci : Disiplin, pegawai negeri sipil, dan KUA 


\section{PENDAHULUAN}

Kantor Urusan Agama Kecamatan Moncongloe Kabupaten Maros merupakan salah satu instansi pemerintah yang melayani masyarakat dalam hal keagamaan sehingga membutuhkan integritas pegawai yang tinggi. Kinerja pegawai atau aparat yang baik akan mewujudkan kinerja organisasi yang baik secara keseluruhan. Pegawai merupakan aset organisasi yang sangat berharga yang harus dikelola dengan baik agar dapat memberikan kontribusi yang optimal. Melihat pentingnya pegawai dalam setiap organisasi, maka pegawai diperlukan perhatian lebih serius terhadap tugas yang dikerjakan sehingga tujuan organisasi dapat tercapai. Salah satu hal yang harus menjadi perhatian utama adalah disiplin kerja para pegawainya, karena pegawai yang dalam bekerja mereka tidak disiplin, maka secara otomatis tidak dapat fokus dan berkonsentrasi secara penuh terhadap pekerjaannya (Ali dan Syamsu Alam, 2012).

Penegakan merupakan istilah yang sudah sering kita dengar dalam kehidupan sehari-hari utamanya terkait dengan masalah hukum atau aturan. Sepertinya masyarakat kita sudah sangat memahami apa itu penegakan aturan, sehingga dalam menyebut istilah penegakan aturan "biasanya" dibarengi dengan ungkapan sinis dan keraguan. (Mathis dan Jackson 2002).

Menurut Kamus Bahasa Indonesia (Depdiknas : 2000) arti penegakan adalah menurut kamus besar Indonesia adalah proses, cara, perbuatan menegakkan atau penanaman. karena kurang atau tidak disiplin. Banyak agenda yang telah ditetapkan tidak dapat berjalan karena kurang disiplin. Menanamkan prinsip agar peserta didik memiliki pendirian yang kokoh merupakan bagian yang sangat penting dari strategi menegakkan disiplin.

Penegakan disiplin menurut Anwar (2001) antara lain dapat dilakukan dengan beberapa cara sebagai berikut:

Peningkatan motivasi. Motivasi merupakan latar belakang yang menggerakkan atau mendorong orang untuk melakukan sesuatu.

Pendidikan dan latihan. Pendidikan dan latihan merupakan salah satu 
faktor penting dalam membentuk dan menempa disiplin. Kepemimpinan. Kualitas kepemimpinan dari seorang pemimpin, turut menentukan berhasil atau tidaknya dalam pembinaan disiplin.

Penegakan aturan. Penegakan disiplin biasanya dikaitkan penerapan aturan (rule enforcement). Idealnya dalam menegakkan aturan hendaknya diarahkan pada "takut pada aturan bukan takut pada orang".

Penerapan reward and punishment. Reward and punishment atau penghargaan dan hukuman merupakan dua kesatuan yang tidak terpisahkan.

Disiplin adalah prosedur yang mengoreksi atau menghukum bawahan karena melanggar peraturan atau prosedur. Disiplin merupakan bentuk pengendalian diri pegawai dan pelaksanaan yang teratur dan menunjukan tingkat kesungguhan tim kerja di dalam sebuah organisasi. Pendisiplinan pegawai adalah suatu bentuk pelatihan yang berusaha memperbaiki dan membentuk pengetahuan, sikap dan perilaku pegawai sehingga para pegawai dapat bekerja secara kooperatif dengan pegawai yang lain serta meningkatkan prestasi kerjanya (Hasibuan, 2013).

Secara etimologi dalam Kamus Besar Bahasa Indonesia (2003:268) disiplin adalah tata tertib sekolah, kemiliteran, dan lain sebagainya (ketaatan/kepatuhan terhadap tata tertib di sekolah).

Disiplin merupakan suatu sikap menghormati, menghargai, patuh, dan taat terhadap peraturan peraturan yang berlaku, baik yang tertulis maupun tidak tertulis serta sanggup menjalakannya dan tidak mengelak untuk menerima sanksisanksinya apabila ia melanggar tugas dan wewenang yang diberikan kepadanya (Siswanto, 2003).

Disiplin ialah setiap usaha mengkoordinasikan perilaku seseorang pada masa yang akan dating dengan mempergunakan hukum dan ganjaran (Flippo, 2003).

Disiplin dapat diartikan bila mana pegawai selalu datang dan pulang pada tepat waktu yang ditentukan oleh kepala manejer pimpinan dari masing-masing instansi (Fathoni, 2006).

Disiplin merupakan kesadaran dan kesediaan seseorang yang 
menaati peraturan organisasi dan norma-norma sosial yang berlaku. Hal ini ditunjukan dari sikap pegawai yang secara sukarela menaati semua peraturan kantor baik yang tertulis maupun tidak tertulis dan sadar akan tugas dan tanggungjawabnya. Menurut Dolet (2003) bahwa disiplin sebagai keadaan ideal dalam mendukung pelaksanaan tugas sesuai aturan dalam rangka mendukung optimalisasi kerja. Disiplin yang baik mencerminkan besarnya tanggung jawab pegawai terhadap tugas-tugas yang diberikan.

Disiplin lebih banyak bersumber dari dalam diri pegawai itu sendiri yang diperlihatkan dalam bentuk mematuhi peraturan yang ada, menyelesaikan tugas tepat waktu. Tingkat kedisiplinan ini merupakan salah satu fungsi kegiatan manajemen sumber daya manusia yang terpenting dan harus lebih diperhatikan, karena semakin baik disiplin pegawai, maka akan semakin tinggi kinerja yang dapat dicapainya. Sulit bagi pegawai dalam mencapai kinerja yang diharapkan tanpa adanya disiplin kerja yang baik dan bertanggungjawab yang ditunjukkan oleh pegawai bersangkutan. Tanpa disiplin pegawai dengan baik dan adil, sulit pula bagi organisasi untuk mencapai hasil optimal yang ingin diharapkan pada pegawainya.

Pegawai Negeri Sipil sebagai aparatur pemerintah sudah seharusnya mempunyai tanggungjawab dan kedisiplinan yang tinggi untuk melaksanakan tugas dan kewajiban sesuai dengan peraturan perundangundangan yang mengaturnya. Ada beberapa peraturan perundangundangan di Indonesia yang mengatur Pegawai Negeri Sipil, salah satu diantaranya adalah Peraturan Pemerintah No. 53 Tahun 2010 tentang disiplin Pegawai Negeri Sipil. Di dalam peraturan tersebut berisi mengenai kewajiban, larangan dan sanksi bagi Pegawai Negeri Sipil yang tidak melakukan kewajibannya serta melanggar larangan yang diatur dalam peraturan tersebut.

Jiwa kepegawaian yang mempunyai sifat seperti tersebut di atas akan berakibat negatif terhadap prestasi kerja pegawai negeri yang bersangkutan karena tidak adanya pengembangan pola pikir kerja sama dan pemakaian kelengkapan peralatan 
dalam mendukung kelancaran tugas. tanggung jawabnya dengan baik. Berdasarkan pada hal tersebut, Dalam rangka menjamin tata tertib Pegawai Negeri Indonesia dan kelancaran pelaksanaan tugas dipandang masih banyak pekerjaan, telah dibuat suatu kekurangan yaitu kurang adanya ketentuan Peraturan Disiplin pegawai menghargai waktu, mengefisienkan Negeri Sipil, sebagai suatu peraturan tenaga dan kedisiplinan kerja. yang membuat keharusan, larangan, Pembinaan Pegawai Negeri Sipil dan sanksi apabila keharusan tidak diatur dalam pasal 12 ayat (2) UU No. dilaksanakan atau larangan dilanggar 5 tahun 2014 tentang Aparatur Sipil Negara (ASN) yaitu agar Pegawai (Nawawi, 2003).

ASN bukan saja unsur aparat Negeri Sipil dapat melaksanakan tugasnya secara berdaya guna dan berhasil guna, maka perlu diatur pembinaan Pegawai Negeri Sipil secara menyeluruh yaitu suatu pengaturan pembinaan yang berlaku baik Pegawai Negeri Sipil pusat maupun Pegawai Negeri Sipil yang ada ditingkat daerah.

Dalam meningkatkan kedisiplinan Pegawai Negeri Sipil, pemerintah telah memberikan suatu kebijaksanaan dengan di keluarkannya Peraturan Pemerintah Nomor 53 tahun 2010 yaitu tentang Disiplin Pegawai Negeri Sipil Pegawai Negeri Sipil sebagai aparat pemerintah dan abdi masyarakat diharapkan selalu siap sedia menjalankan tugas yang telah menjadi 
harus di utamakan.

Berdasarkan

Peraturan

Pemerintah No. 53 Tahun 2010, hukuman disiplin adalah hukuman yang dijatuhkan kepada Pegawai Negeri Sipil karena melanggar Peraturan Disiplin Pegawai Negeri Sipil. Di dalam Peraturan Pemerintah Nomor 30 Tahun 1980 Tentang Peraturan Disiplin Pegawai Negeri Sipil pada Pasal 6 memuat tingkat dan jenis hukuman disiplin, yaitu : Hukuman disiplin ringan, terdiri dari teguran lisan, teguran tertulis, dan pernyataan tidak puas secara tertulis, . Hukuman disiplin sedang, terdiri dari penundaan kenaikan gaji berkala untuk paling lama satu tahun, penurunan gaji sebesar satu kali kenaikan gaji berkala untuk paling lama satu tahun, penundaan kenaikan pangkat untuk paling lama satu tahun, dan. Hukuman disiplin berat, terdiri dari penurunan pangkat pada pangkat setingkat lebih rendah untuk paling lama satu tahun, pembebasan dari jabatan, pemberhentian dengan hormat tidak atas permintaan sendiri sebagai Pegawai Negeri Sipil, dan pemberhentian tidak dengan hormat sebagai Pegawai Negeri Sipil.
Pemberian hukuman disiplin pegawai tersebut harus ditegakkan. Pada dasarnya penegakan disiplin adalah mendidik agar seseorang taat pada aturan dan tidak melanggar larangan yang dilandasi oleh sebuah kesadaran. Penegakan disiplin biasanya dikaitkan penerapan aturan (rule enforcement) (Azwar, 2001). Idealnya dalam menegakkan aturan hendaknya diarahkan pada takut pada aturan bukan takut pada orang. Jika hal ini tumbuh menjadi suatu kesadaran maka menciptakan kondisi yang nyaman dan aman sehingga dapat memberikan kinerja yang optimal.

\section{METODE PENELITIAN}

Penelitian ini dilaksanakan pada bulan Januari sampai Maret tahun 2017 di Kantor Urusan Agama Kecamatan Moncongloe Kabupaten Maros. Jenis penelitian ini adalah penelitian kualitatif dengan tipe penelitian deskriptif yang berfokus pada perilaku kedisiplinan PNS pada Instansi Pemerintah. Informan dalam penelitian ini terdiri atas lima orang, dimana dipilih secara purposive. 
Data yang digunakan dalam penelitian adalah data primer dan data sekunder. Data primer merupakan data yang diperoleh secara langsung dari sumber pertama dan pihak-pihak terkait dengan cara observasi dan wawancara. Data sekunder merupakan data diperoleh melalui buku-buku, makalah, hasil penelitian, internet, opini, dan surat kabar yang relevan dengan permasalahan yang diteliti.

Data yang diperoleh dilakukan pegecekan keabsahan data dengan teknik pemeriksaan derajat kepercayaan (credibility), keteralihan (transferability), ketergantungan (dependability), dan konfirmabilitas. (Lexi 2002; \& Arifin 2011). Data yang diperoleh dan dikumpulkan dari hasil penelitian, dianalisis secara kualitatif. Metode kualitatif merupakan suatu metode analisis data yang didasarkan pada pemahaman dan pengolahan data secara sistematis yang diperoleh dari hasil wawancara dengan responden, narasumber, dan hasil penelitan kepustakaan (Sugiyono, 2013).

\section{HASIL DAN PEMBAHASAN}

Kedisiplinan pegawai merupakan fungsi operasional manajemen sumber daya manusia yang sangat penting bagi kelangsungan organisasi, karena semakin baik kedisiplinan pegawai, semakin tinggi prestasi kerja yang dicapainya. Tanpa adanya disiplin kerja yang baik dari pegawai, sulit bagi setiap instansi pemerintah mencapai hasil yang maksimal dalam mencapai tujuan. Oleh karenanya, adalah sangat penting penegakan disiplin kerja Pegawai Negeri Sipil dalam setiap instansi pemerintah, terutama untuk memotivasi pegawai agar dapat mendisiplinkan diri dalam melaksanakan pekerjaan, baik secara perorangan maupun kelompok, untuk mematuhi dan menyenangi peraturan, prosedur, maupun kebijakan yang ada, sehingga dapat menghasilkan kinerja yang baik.

Pegawai merupakan aset organisasi yang sangat berharga yang harus dikelola dengan baik agar dapat memberikan kontribusi yang optimal. Melihat pentingnya pegawai dalam setiap organisasi, maka pegawai diperlukan perhatian lebih serius 
terhadap tugas yang dikerjakan sehingga tujuan organisasi dapat tercapai. Salah satu hal yang harus menjadi perhatian utama adalah disiplin kerja para pegawainya, karena pegawai yang dalam bekerja mereka tidak disiplin, maka secara otomatis tidak dapat fokus dan berkonsentrasi secara penuh terhadap pekerjaannya

Adapun sistem prestasi kerja adalah sistem kepegawaian, dimana pengangkatan seseorang untuk menduduki suatu jabatan atau untuk kenaikan pangkat di dasarkan atas kecakapan dan prestasi kerja yang di capai oleh pegawai. Kecakapan tersebut harus dibuktikan dengan lulus dalam ujian dinas dan prestasi dibuktikan secara nyata dan sistem prestasi kerja ini tidak memberikan penghargaan terhadap masa kerja.

ASN bukan saja unsur aparat negara tetapi juga merupakan Abdi Negara dan Abdi Masyarakat yang selalu hidup ditengah masyarakat dan bekerja untuk kepentingan masyarakat. Oleh karena itu dalam pelaksanaan pembinaan ASN bukan saja di lihat dan diperlakukan sebagai aparatur negara, tetapi juga dilihat dan diperlakukan sebagai warga negara. Hal ini mengandung pengertian, bahwa dalam melaksanakan pembinaan hendaknya sejauh mungkin diusahakan adanya keserasian antara kepentingan dinas dan kepentingan pegawai negeri sebagai perorangan, dengan ketentuan bahwa apabila ada perbedaan antara kepentingan dinas dan kepentingan pegawai negeri sebagai perorangan, maka kepentingan dinaslah yang harus di utamakan.

Kaitannya Dengan kedisiplinan, Kantor Urusan Agama Kecamatan Moncongloe sebagai lembaga dibawah Kementerian Agama Republik Indonesia, maka kedisiplinan pegawai sangat penting untuk menciptakan pemerintah yang bersih dan berwibawa. Bertitik tolak dari uraian tersebut di atas, maka untuk mewujudkan aparatur Pemerintahan yang bersih dan berwibawa, kedisiplinan Pegawai Negeri Sipil merupakan salah satu faktor yang sangat menentukan, Pegawai Negeri Sipil sebagai Aparat Pemerintah, abdi negara dan abdi masyarakat harus bisa menjadi suri tauladan terhadap masyarakat secara 
keseluruhan, sehingga masyarakat dapat percaya terhadap peran ASN.

Kantor Urusan Agama Kecamatan Moncongloe sendiri telah mengimplementasikan peraturan disiplin Pegawai Negeri Sipil, tetapi tidak menutup kemungkinan untuk PNS Kantor Urusan Agama Kecamatan Moncongloe untuk melakukuan hal-hal yang dapat menurunkan kehormatan atau martabat Negara, Pemerintah, atau ASN, dalam hal ini ada Pegawai Negeri Kantor Urusan Agama Kecamatan Moncongloe yang mangkir dari tugasnya, penyalahgunaan kewenangan, menyalahgunakan barang- barang, uang, atau surat-surat berharga milik Negara, melakukan kegiatan bersama dengan atasan, teman sejawat, bawahan, atau orang lain di dalam maupun di luar lingkungan kerjanya dengan tujuan untuk keuntungan pribadi, golongan, atau pihak lain, yang secara langsung atau tidak langsung merugikan Negara, menerima hadiah atau sesuatu pemberian berupa apa saja dari siapapun yang bersangkutan dengan jabatan atau pekerjaan Pegawai
Negeri Sipil, memasuki tempattempat yang dapat mencemarkan kehormatan atau martabat Pegawai Negeri Sipil, kecuali untuk kepentingan jabatan, bertindak sewenang-wenang terhadap bawahan, hal ini dapat mengakibatkan kerugian bagi Negara.

Faktor disiplin dipandang sebagai suatu aspek yang penting karena melalui disiplin ini dapat diciptakan kesadaran dari setiap pribadi setiap anggota organisasi terhadap eksistensinya serta konstribusi yang dituntut dari padanya dalam rangka mencapai tujuan organisasi dan pribadinya. Namun dalam kenyataannya faktor kedisiplinan Pegawai Negeri Sipil sering mendapat sorotan tajam dari masyarakat, karena masih banyak kasus-kasus pelanggaran disiplin ringan yang dilakukan oleh Pegawai Negeri Sipil. Ketidakdisiplinan Pegawai Negeri Sipil Kecamatan Moncongloe Kabupaten Maros adalah kurangnya kepedulian pegawai terhadap disiplin, mangkir bekerja atau meninggalkan tugas, dan tidak menjalankan tugas yang diberikan. 
Terjadinya suatu pelanggaran disiplin tidak terlepas dari latar belakang melakukan tindakan tersebut, adanya unsur kurang kesadaran dan ketaatan terhadap peraturan serta menganggap ringan segala upaya tindakan penegakan yang ada. Penegakan aturan disiplin merupakan kunci untuk mengatasi segala pelanggaran disiplin yang ada, tetapi kunci dari penegakan aturan disiplin ini tidak terlepas dari beberapa faktor yang mendukungnya.

Berbicara mengenai pelanggaran disiplin tentu berbicara pula mengenai penegakan disiplin sebagai antisipasi dari pelanggaran tersebut. Dimana penegakan disiplin merupakan suatu cara yang digunakan oleh lembaga atau badan pemerintahan dalam memberikan hukuman atau sanksi kepada para pegawai yang terbukti melanggar kedisiplinan. Mengacu kepada Peraturan Pemerintah No. 53 Tahun 2010, maka salah satu pihak yang sangat berperan dalam penegakan disiplin Pegawai Negeri Sipil adalah atasan. Ini berarti bahwa, penegakan disiplin Pegawai Negeri Sipil dalam lembaga pemerintahan, tergantung pada upaya pembinaan yang dilakukan oleh atasan Pegawai Negeri Sipil tersebut.

$$
\text { Penegakan disiplin kerja akan }
$$
berjalan dengan optimal jika ada kesadaran dalam diri setiap pegawai. Misalnya pegawai datang ke kantor dengan tepat waktu dan mentaati semua peraturan-peraturan yang berlaku. Penegakkan disiplin kerja Pegawai Negeri Sipil di Kecamatan Moncongloe itu berjalan dengan baik. Kepala Kantor Urusan Agama melakukan pendekatan self imposed dicipline dalam penegakkan disiplin kerja pegawai, karena kedisiplinan pegawai bisa berjalan dengan baik ketika ada kesadaran dalam diri pegawai yang bersangkutan. Disamping itu, keteladanan yang ditunjukan oleh Kepala Kantor Urusan Agama Kecamatan Moncongloe memberikan dampak positif dalam penegakkan disiplin kerja. Pegawai dapat bekerja berdasarkan peraturan, prosedur, maupun kebijakan yang ada. Keteladanan Kepala Kantor Urusan Agama Kecamtan Moncongloe Kabupaten Maros, mampu mendorong pegawai dalam melaksanakan kedisiplinan karena 
pimpinan selalu memberikan contoh bagi para bawahannya, yaitu dengan cara datang tepat waktu, memberikan bimbingan kepada pegawai, dan tegas dalam mengambil keputusan.

\section{Kepala Kantor Urusan Agama} Kecamatan Moncongloe, menegakkan beberapa upaya dalam penegakkan disiplin kerja pegawai. Upaya-upaya tersebut adalah melakukan pendekatan preventif dan represif. Pendekatan preventif yakni melakukan pembinaan disiplin yang terus-menerus setiap hari kepada pegawai, agar pegawai mampu melaksanakan tugas kantor dengan efektif dan efisien. Pembinaan dilakukan dengan tujuan untuk menghasilkan pegawai yang bermutu dan berkualitas yang berdaya guna dan berhasil guna, yang dilakukan secara sistematis dan pemanfaatan potensi dan kemampuan sesuai dengan kebutuhan organisasi. Sedangkan pendekatan represif dilakukan dengan pemberian sanksi hukuman disiplin kepada pegawai yang indisipliner. Pemberian hukuman sangat diperlukan dalam upaya penegakan kedisiplinan pegawai, untuk mendidik pegawai

supaya menaati semua peraturan yang telah dibuat. Pemberian hukuman merupakan upaya yang tergolong menimbulkan efek jera, dan bermanfaat untuk mendidik pegawai mematuhi peraturan, prosedur dan kebijakan yang ada.

Suatu disiplin akan dapat ditegakan, bila disamping aturan tertulis yang terjadi pegangan bersama, juga perlu sanksi hokum. Sanksi hukum tidak hanya tertulis diatas kertas saja, tetapi benar-benar dilaksanakan dalam praktek seharihari. Maka perlu adanya keberanian pimpinan untuk mengambil tindakan yang sesuai dengan tingkat pelanggaran yang dibuatnya.

Sanksi hukum adalah
hukuman yang dijatuhkan pada
seseorang yang melanggar hukum.
Sanksi hukuman berperan penting
dalam memelihara kedisiplinan
pegawai. Karena dengan adanya
sanksi hukuman yang semakin berat,
pegawai akan semakin takut
melanggar peraturan-peraturan
organisasi, sikap dan perilaku
indisipliner pegawai akan berkurang.
Berat ringannya sanksi hukuman
yang akan diterapkan ikut


mempengaruhi baik buruknya faktor-faktor yang mendorong kedisiplinan pegawai. Penerapan dilakukan pelanggaran tersebut.

hukuman yang diberikan kepada

Pegawai Negeri Sipil Kecamatan Moncongloe Kabupaten Maros berdasarkan prosedur-prosedur yang telah ditetapkan dari hukuman ringan, hukuman sedang dan hukuman berat.

Penerapan hukuman disiplin pegawai dijatuhkan pada seseorang yang melanggar aturan dan tata tertib.

Penerapan hukuman berperan penting dalam memelihara tingkat kedisiplinan pegawai. Dengan hukuman yang semakin berat, pegawai akan semakin takut melanggar peraturan-peraturan, sikap dan perilaku indisipliner pegawai akan berkurang. Berat atau ringannya sanksi hukuman yang akan diterapkan ikut mempengaruhi baik atau buruknya kedisiplinan pegawai. Dalam menjatuhkan hukuman disiplin, maka yang berwenang menghukum sebelumnya wajib memeriksa terhadap tersangka yang telah melanggar ketentuan. Tujuannya ialah untuk mengetahui apakah yang bersangkutan benar telah melakukan pelanggaran serta untuk mengetahui
Hukuman yang dapat dijatuhkan sebagai sanksi terhadap pelanggaran disiplin Pegawai Negeri Sipil telah tertuang dalam Peraturan Pemerintah Nomor 53 Tahun 2010 yakni : Hukuman disiplin ringan, berupa teguran lisan, teguran tertulis dan pernyataan tidak puas secara tertulis. Hukuman disiplin sedang, berupa penundaan kenaikan gaji berkala untuk paling lama satu tahun, penurunan gaji sebesar satu kali kenaikan gaji berkala untuk paling lama satu tahun, dan penundaan kenaikan pangkat untuk paling lama satu tahun, hukuman disiplin berat, penurunan pangkat pada pangkat yang setingkat lebih rendah untuk paling lama satu tahun, pembebasan dari jabatan, pemberhentian dengan hormat tidak atas permintaan sendiri sebagai Pegawai Negeri Sipil, dan pemberhentian dengan tidak hormat sebagai Pegawai Negeri Sipil.

Penerapan hukuman disiplin Pegawai Negeri Sipil berdasarkan pertimbangan dari atasan dan harus dilakukan secara adil melalui 
prosedur-prosedur yang telah digunakan dalam memberikan ditetapkan. Tindakan hukuman hukuman atau sanksi kepada para disiplin merupakan langkah terakhir pegawai yang terbukti melanggar yang digunakan dalam melakukan pengawasan atau supervise kepada kedisiplinan.

Visi kami adalah memberikan para pegawai. Dengan adanya hukuman disiplin dapat mendidik dan mengoreksi kesalahan yang dilakukan sehingga dapat memeperbaiki dan tidak melakukan kesalahan yang sama. Penerapan hukuman disiplin pegawai di Kantor Urusan Agama Kecamatan Moncongloe Kabupaten Maros terdiri hukuman ringan, hukuman sedang, dan hukuman berat. Hukuman ini dilakukan untuk mengarahkan dan memperbaiki perilaku pegawai dan bukan untuk menyakitinya.

\section{Berbicara mengenai} penegakkan disiplin tentu berbicara pula mengenai pelanggaran. Memperhatikan pelanggaran disiplin itu terjadi karena tidak adanya kesadaran dari pegawai itu sendiri. Misalnya, pegawai tidak bisa datang dan pulang tepat waktu. Dalam kondisi seperti ini membutuhkan keteladanan seorang pemimpin. Penegakan disiplin disini kan merupakan suatu cara yang pelayanan yang terbaik kepada masyarakat. Jika ingin pelayanan bagus dimata masyarakat, tentunya kita tidak boleh mempersulit masyarakat ketika mereka berurusan dalam kantor. Kami tidak boleh memberikan pelayanan yang kurang responsive, apalagi misalnya tidak mengikuti prosedur yang telah ditetapkan.

Penerapan hukuman disiplin Pegawai Negeri Sipil di Kantor Urusan Agama Kecamatan Moncongloe Kabupaten Maros berdasarkan prosedur-prosedur yang telah ditetapkan. Pemberian hukuman disiplin yang dilakukan adalah hukuman disiplin ringan. Hal ini ditunjukan oleh pemberian peringatan dan teguran secara lisan oleh Kepala Kantor Urusan Agama. Pemberian peringatan di Kantor Urusan Agama Kecamatan Moncongloe Kabupaten Maros sudah berjalan sesuai dengan Peraturan Pemerintah Nomor 53 
Tahun 2010. Misalnya bagi pegawai Negeri Sipil, yang sering terlambat masuk kerja, bersantai-santai dan meninggalkan kantor sebelum waktu yang talah ditetapkan, pertama akan diberi peringatan secara lisan oleh pimpinan dan jika pegawai masih mengulanginya maka akan diberi surat teguran secara tertulis. Jika masih mengulanginya maka akan dihukum sesuai dengan prosedur yang ada. Pemberian hukuman disiplin tersebut segera dilakukan dengan tujuan agar semua pegawai merasa jera dan enggan untuk mengulangi kesalahan lagi. Disamping itu, pemberian sanksi dilakukan secara adil, dan tidak membeda-bedakan.

\section{KESIMPULAN}

$$
\text { Adapun yang menjadi }
$$

kesimpulan dalam penelitian ini adalah: Penegakan disiplin Pegawai Negeri Sipil di Kantor Urusan Agama Kecamatan Moncongloe Kabupaten Maros berjalan dengan baik karena Kepala Kantor Urusan Agama melakukan pendekatan self imposed dicipline dalam penegakkan disiplin kerja pegawai. Disamping itu, keteladanan yang ditunjukan oleh Kepala Kantor Urusan Agama Kecamatan Moncongloe memberikan dampak positif dalam penegakkan disiplin kerja, dan. Penerapan hukuman disiplin Pegawai Negeri Sipil di Kantor Urusan Agama Kecamatan Moncongloe Kabupaten Maros berdasarkan prosedurprosedur yang telah ditetapkan. Pemberian hukuman disiplin yang dilakukan adalah hukuman disiplin ringan. Hal ini ditunjukan oleh pemberian peringatan dan teguran secara lisan oleh Kepala Kantor Urusan Agama.

\section{DAFTAR PUSTAKA}

Ali, Faried dan Andi Syamsu Alam. 2012. Studi Kebijakan Pemerintah. Bandung: PT. Refika Aditama.

Anwar Prabu Mangkunegara, 2001. Mananejem Sumber Daya Manusia Perusahaan. Bandung: Remaja Rosdakarya

B. Siswanto Sastrohadiwiryo, 2003, Manajeemen Tenaga Kerja Indonesia, edisi, 2, Jakarta, PT. Bumi Aksara

Depdiknas. 2000. Kamus Besar Bahasa Indonesia. Jakarta : Balai Pustaka 
Dolet, Unaradjan. 2003 Manajemen Disiplin. Jakarta : PT. Gramedia Widiasarana Indonesia

Fathoni, Abdurrahmat. 2006. Organisasi dan Manajemen Sumber Daya Manusia. Jakarta : Rineka Cipta

Flippo, B. Edwin, 2003, Manajemen Personalia, Jakarta Erlangga

Mathis R.L dan Jackson J.H. 2002. Manajemen Sumber Daya Manusia, Salemba Empat, Jakarta
Malayu.S.P. Hasibuan. 2013. Manajemen Sumber Daya Manusia. Edisi Revisi, Cetakan Keenambelas. Jakarta: Bumi Aksara.

Nawawi, Hadari. 2003. Pengawasan Melekat Di Lingkungan Aparatur Negara. Jakarta: Erlangga.

Peraturan Pemerintah No.53 Tahun 2010 tentang Disiplin Pegawai Negeri Sipil.

Undang-Undang Nomor 5 Tahun 2014 tentang Aparatur Sipil Negara 